\title{
The Minjung Millenarianism of Bandy X. Lee
}

\section{Bruce Gilley}

Of all the experts who came forward during the Trump years to declare that the president's administration was in breach of expert opinion, none perhaps will be better remembered than Yale psychiatrist Bandy Xenobia Lee. A hitherto obscure professor, Lee came to attention when she convened a conference of shrinks at Yale in early 2017 to declare that the president was crackers. In three subsequent books, she elaborated the thesis. ${ }^{1}$ Meanwhile, she became an energetic Tweeter, essayist, interviewee, and congressional remonstrator, increasingly convinced of the veracity and urgency of her expert insights.

Lee's advocacy put other critics in a ticklish situation. Trump, as she argued within months of his inauguration, was mentally ill. Thus, in addition to the constitutional question of whether Congress should dust off the Twenty-Fifth Amendment for reasons graver than a colonoscopy-which had brought its most recent deployment under George W. Bush in 2002-the claims implied that other critics were misguided. After all, one could not in fairness assail the president for being illogical, irrational, and impervious to reason if he lacked those very faculties. One might as well reproach beavers for causing mudslides.

Faculties were indeed at the heart of the passionate advocacy of Bandy X. Lee. More than three dozen experts in mental health contributed to her twin books arguing that the president was cuckoo, all with lettered credentials trailing their names like kite ribbons. Their various diagnoses differed to a degree that vindicated the standard punch line about a room

1 Bandy X. Lee, The Dangerous Case of Donald Trump: 27 Psychiatrists and Mental Health Experts Assess a President (New York: St. Martin's Press, 2017); Bandy X. Lee, The Dangerous Case of Donald Trump: 37 Psychiatrists and Mental Health Experts Assess a President (New York: St. Martin's Press, 2019); Bandy X. Lee, Profile of a Nation: Trump's Mind, America's Soul (New York: World Mental Health Coalition, 2020)

Bruce Gilley is a professor of political science at Portland State University, Portland, OR 97207-0751; gilleyb@pdx.edu. 
full of psychiatrists: "impulsivity and recklessness," "lack of foresight," “irrationality," “willful ignorance," "grandiosity," and "narcissistic rage." Other charges included "unbridled and extreme present hedonism," which may be a diagnosis with wide application to the world's youth. ${ }^{3}$ Another verdict, "poor relationship with significant other or spouse," rather took a swipe at much of the adult population of the United States. ${ }^{4}$ Lee, with 11,000 Tweets to her name in under two years, later added "the compulsive need to Tweet" to the bedside chart. While insisting that this was a non-partisan and purely-scientific public service, Lee included in the books essays by Noam Chomsky, Jeffrey Sachs, and Hillary Clinton biographer Gail Sheehy.

In her four years of arguing about the wits of the president, Lee took the idea of expert prerogative to invalidate democratic choices to new heights. To explain the particular forms and language of her campaign, we need to go beyond the standard explanations. Yes, academics are today virtually all on the Left and, under Trump, they were responding to a president who positioned himself unapologetically on the Right with intentional "outrages” designed to provoke indignation in the faculty lounge. The term "Trump Derangement Syndrome" became not so much a clinical as a comedic description of how well he succeeded. At times, reading Lee's description of the "cult-like" dynamics of the Trump presidency, such as gathering at like-minded conferences and being convinced of one's own premises, one could only gasp at the lack of selfawareness. “The healthy persons, the thriving persons are suppressed; whereas the compromised and submissive and instrumental persons are praised," she warned on one occasion. ${ }^{5}$

There were, to be sure, other prominent mind-healers with TDS who published their own books making similar claims of non-compos mentis affecting Trump or the national wits as a whole. ${ }^{6}$ But Lee's advocacy included elements of existential rhetoric and transhistorical visions of the future that were not found among the utterances of her collaborators. To explain this, we need to

2 Harper West, Steve Wruble, and Bandy X. Lee, "Epilogue," Journal of Humanistic Psychology 60, no. 4 (2020/07/01 2020): 549.

3 Philip Zimbardo, Rosemary Sword, "Unbridled and Extreme Present Hedonism: How the Leader of the Free World Has Proven Time and Again He Is Unfit for Duty," in The Dangerous Case of Donald Trump: 37 Psychiatrists and Mental Health Experts Assess a President, ed. Bandy X. Lee (New York: St. Martin's Press, 2019).

4 Bandy X. Lee, "Thousands of Mental Health Professionals Agree with Woodward and the New York Times Op-Ed Author: Trump is Dangerous," The Conversation, September 7, 2018.

5 Interview with Mary Trump, bandylee.com, August 11, 2020.

6 Justin A. Frank, Trump On the Couch: Inside the Mind of the President (New York: Avery, 2018); Allen Frances, Twilight of American Sanity: A Psychiatrist Analyzes the Age of Trump (New York: William Morrow, 2017). 
put Lee herself under the analytical lens. Just as she pointed to the importance of Trump's particular cultural and moral worldviews, we need to understand Lee with reference to her own cultural and symbolic inheritance. As I will argue, the distinctly Korean phenomenon of “minjung millenarianism” provides a powerful lens with which to understand her campaign.

Korean press reports state that Bandy Xenobia (“descended from Zeus") Lee was born in Korea in 1970 and then brought to the United States at aged one and a half by her mother. Her official biography reports her as being born in the U.S. Either way, her formative years were in the Korean immigrant community of New York which, like many immigrant communities, presents as a rarified version of the home culture. Intense religious participation is variously estimated to cover 77 percent to 97 percent of this community. ${ }^{7}$

Lee claims her major inspiration came from her mother's father, who was a physician in Korea in the 1940s and 1950s, a period of devastation that was a critical moment of emergence for the cultural ethos that became known as minjung millenarianism. This philosophy has been described as "a sociotheological biography of the Korean people" and as an expression of "the Korean mind." ${ }^{8}$ It draws upon the historical waves of shamanism, Taoism, Confucianism, Buddhism, and Christianity that have washed over the Korean peninsula over the ages. Recent iterations embrace Islam and Hinduism for good measure. In the millenarian traditions that became central to Korean culture, all these were supposed to be united in a pan-historical, global unity of doctrines. The best known manifestation of this is the Holy Spirit Association for the Unification of World Christianity (the “Moonies"). It is also a critical determinant of the doctrines, practices, and durability of the Democratic People's Republic of Korea, which added Marxism and juche ("self-reliance”) to the syncretic mix. ${ }^{9}$

Like all millenarian worldviews, Korean millenarianism combines three basic principles: the crisis of a world seized by an evil force; the arrival of the messianic leader who scotches the evil force; and the subsequent millennium of peace and prosperity (and good mental health).

7 Soonhee Roh, KyoungHag Lee, DongPil Yoon, "General Well-Being of Korean Immigrant Elders: The Significance of Religiousness/Spirituality and Social Support," Journal of Social Service Research 39, no. 4 (2013)

8 Sang-taek Yi, Religion and Social Formation in Korea: Minjung and Millenarianism (Berlin: Mouton de Gruyter, 1996), ix, 75.

9 Pyong-gyun Kim, The Dialogue Between Minjung Theology, Marxism, Juche Philosophy for Reconciliation and Peace Unification on the Korean Peninsula (in Korean) (Kwangju: Chonbuk Taehakkyo, 2019). 
Unlike elsewhere, millenarianism is central to Korean culture, not a fringe movement. The Korean people, it might be said, are a millenarian people. As a result, it took on a populist minjung (or “people's”) dimension. The minjung aspect brought the project out of the realm of passive waiting and into the realm of everyday action. The people's role was to prepare the way for the messianic leader through vigorous activities against the evil force.

As far as I am aware, Bandy Lee has never espoused adherence to any particular faith tradition as a formal doctrine. That is consistent with the inclusive (some might say indigestible) folk spiritualism of minjung millenarianism. In choosing this framework for understanding her advocacy, I am simply noting the parallels between her work and this most central of doctrines in the culture of her heritage. Unusually for a clinical psychiatrist, she holds a master's degree in divinity from Yale. She has frequently extolled the importance of "the spiritual dimensions" of her work. ${ }^{10}$ She often repeats the claim that "Westerners sharply divide mind from body," ${ }^{11}$ a claim that allows her to emphasize her Eastern spirituality. Her medical school thesis was about how to use quantum physics in the consultation room. ${ }^{12}$ The minjung millenarian framework offers one way to understand how an obscure psychiatrist threw herself into vigorous action against a perceived evil force.

The sixteenth century collection of stories Revelations of Monk Jung (Jung Kam Lok) is a foundational text of minjung millenarianism. In it, Monk Jung describes the evil that will shadow the land, complete with famines, comets, sexual immorality, and scholars "who wear their hats crookedly." ${ }^{13}$ The king would be corrupt and childish, stooping so low as to allow commoners to pass the government examination. In another foundational text of minjung millenarianism, which serves as the basis of today's popular Heavenly Way (Cheondogyo) group in South Korea, a "social disease” would afflict the people and as a result the government would be racked by infighting.

Lee's language about Trump left little doubt that she saw his election as a trans-historical and supernatural evil. “Trump's illness is a symptom in the current chaos and disorder," she warned. ${ }^{14}$ "In the most extreme situation, he

10 Bandy Lee, "The Symbolism (or Spiritual Causes) of Violence," in Violence: An Interdisciplinary Approach to Causes, Consequences, and Cures, ed. Bandy Lee (New York: John Wiley, 2019).

11 Bandy X. Lee, "Why Donald Trump Threatens Public Health As Much As The Coronavirus," DCReport.com, 6 February 2020.

12 Bandy X. Lee, Steps Toward a New Psychiatry: Quantum Physical Implications for Psychiatric Theory and Practice, 1995

13 Yi, Religion and Social Formation in Korea: Minjung and Millenarianism, 69.

14 Jin-gu Lee, "He said 'I Have to Shoot You Before Trump Gets Attacked'," Dongaa.com, (In Korean), March 
may readily cross over to annihilating the world and himself," she added. ${ }^{15}$ She told Salon magazine that "a malignant reality is taking hold" and that "our survival as a species may be at stake." ${ }^{16}$ She believed that her book "could be the key to the future of human survival." ${ }^{17}$ She told Newsweek that she worried daily about "the extinction of the human species" if Trump was not forcibly removed from office. ${ }^{18}$ Trump had caused the "usurpation of the people's freedom to think." ${ }^{19}$ In one video, she called Trump "a mass killer" because of his handling of COVID: “Trump's mentally deranged pathology is a weapon of mass destruction which will destroy America if given four more years." 20 Trump was an evil genius: “Atrocities such as genocide (or democide) become possible." 21 She believed "he will continue to push for the maximal number of deaths possible"22 because "his psychopathology favors deaths." 23

Her followers were warned not to fall for his disguises as a kindly monk, a common trope in minjung millenarianism: "The words and gestures that arouse the most sympathy are the worst manipulations intended to prey upon you," she warned after Trump's condolences on the death of Justice Ginsburg. ${ }^{24}$ The "fervor of his rallies" was evidence of the evil spreading. 25 "Those whose minds are controlled are the last persons on Earth who will wish to admit that their minds are being controlled," she Tweeted about Trump supporters. ${ }^{26}$ In a similar vein, she warned “The more his followers' minds are controlled, and the more horrific his oppression and massacre of the people.” ${ }^{27}$

In the minjung millenarian tradition, this existential evil prompts the minjung into action. Those who are the first to raise the alarm return from

26, 2018.

15 Dean Haycock, "Interview With Yale Forensic Psychiatrist Bandy Lee," Psychology Today, July 10, 2020.

16 Chauncey Devega, "Psychiatrist Bandy Lee: "We have an obligation to speak about Donald Trump's mental health issues. . . . Our survival as a species may be at stake," Salon, May 25, 2017.

17 Elaine Godfrey, "The Psychiatrist Telling Congress Trump Could Be Involuntarily Committed," The Atlantic, January 12, 2018.

18 Kate Sheridan, "Trump Could Destroy the Entire Human Species, Says Yale Psychiatrist Who Warned Congress Members," Newsweek, January 6, 2018.

19 Bandy Lee Tweet, Dec 30, 2019.

20 The MeidasTouch.com Twitter feed, September 1, 2020, https://twitter.com/i/status/1300972681886461955.

21 Bandy Lee, "There's A Madman In The White House ... And He's Getting Worse," DCReport, October 18, 2020.

22 She wrote in DCReport.com (March 30 2020)

23 Bandy Lee, "The Trump Mental Health Pandemic," Medium.com, 15 August 2020.

24 Bandy Lee Tweet, September 24, 2020.

25 Lee, "Thousands of Mental Health Professionals Agree with Woodward and the New York Times OpEd Author: Trump is Dangerous."

26 Bandy Lee Tweet, December 1, 2020

27 "Psychiatric expert: Trump will not hesitate to cause violence to stay in power," AlterNet, 20 November 2020, https://www.alternet.org/2020/11/trump-authoritarian/ 
their mountain redoubts (where the stones have turned white) to fight against the evil regime. The reason, in Cheondogyo teaching, is that they alone are the "heavenly-minded" and thus in a position to diagnosis the national mental illness. "Without controlling their minds, they will not recover," a sage warns of the deplorables who followed the evil leader. ${ }^{28}$ Revolutionary heroes in Korean culture are not Latin American-style militants in berets sheathed with ammo belts, but sage-like occultists who preach spiritual and mental enlightenment after coming out of the mountains. ${ }^{29}$

Bandy Lee's activism is widely cited by her collaborators as going above and beyond normal duty. She led the movement, because she was the most active. Going beyond the standard academic playbook, she took the narrow problem of Trump and escalated it into a global mental health crisis. Her solution, the World Mental Health Coalition, was so ambitious in scope that visitors to the website might have been excused for wondering if it also accepted mass wedding bookings. "I realized that this was unprecedented, that we had a medical consensus not only among those of the same specialty but among mental health professionals globally," she explained. Through this new movement, she enthused, "millions have chosen the path of new or renewed activism." If the nation as a whole was under the evil spell, then her small band of sages in the mountains would bring some juche to bear. "An invigorated ethos of activism may be the beacon necessary to lead us out of this Dark Age.”30

The coming of the messiah in the minjung millenarian tradition heralds the end of the evil. What was distinctive about the messianism of Korean culture was that the messiah would speak in the technical language of geomancy, whereas most messianic traditions involve a messiah who speaks directly and intelligibly (as in Jesus's use of earthy parables). The minjung are not given action-ready bromides about loving their neighbors (with the exception of their neighbors' wives). Instead, the messiah is a person of occult learning and expertise, not some crooked-hat scholar with a fake examination diploma. The people are promised that "if they become heavenly minded, they will recover," the sage of Cheongdogyo promises. "Through mental, social, and national

28 Yi, Religion and Social Formation in Korea: Minjung and Millenarianism, 119.

29 Chung Moo Choi, "The Minjung Culture Movement and the Construction of Popular Culture in Korea," in South Korea's Minjung Movement: The Culture and Politics of Dissidence, ed. Kenneth Wells (Hawaii: University of Hawaii Press, 1995).

30 West, Wruble, and Lee, "Epilogue," 552. 
innovations, social disease would be cured and the Earth would become a utopia." 31

Lee sometimes described herself in messianic terms, comparing herself to the Tank Man of Tiananmen Square on one occasion. ${ }^{32}$ Her story of being summoned by members of Congress to provide a briefing reads like a Dear Leader story: "I was immensely humbled when one of them called me his 'hero." ${ }^{33}$ Her origin story begins with Trump's election: “So it was really that morning after the election, starting at 8 a.m., when my phone was ringing off the hook, that I thought if I devoted most of my life to preventing violence, why would I refrain from being involved in the greatest risk to human safety and survival-in fact the survival of the human species?" 34

What exactly the millennium of good mental health is supposed to look like is anyone's guess. While Lee rejoiced that "the healthy part of the population" 35 won the 2020 election, the unhealthy half who had "handed over their agency and rationality" ${ }^{36}$ would remain a grave threat to the country. The 74 million new psychotherapy patients she thereby enrolled on November $7^{\text {th }}$ would require "emotional support" and "reduction of exposure to cultic programming." The one remedy that was off-limits for this defender of democracy was civic debate: "I do not recommend argument or attempts at persuasion." ${ }^{37}$

The reason for taking Lee seriously post-Trump is that this longer game remains in play. The occult learning about recovery requires nothing less than a complete reformation of global society, in Lee's view. She is part of a faction in her field that sees all forms of real and perceived social injustice as "violence," and thus urges a medicalization of what most people consider normal political and social pluralism. ${ }^{38}$

Lee's millenarian activism, then, represented a remarkable act of intellectual pole vaulting, taking the humble field of psychiatry and thrusting it to the commanding heights of politics with the ability to decide things such as the marginal tax rate and when to withdraw troops from Syria. Alongside

31 Yi, Religion and Social Formation in Korea: Minjung and Millenarianism, 119.

32 West, Harper, Steve Wruble, Bandy X. Lee. "Addressing the Elephant in the Room: Stories of Ethical Activism in the Age of Trump." Journal of Humanistic Psychology 60, no. 4 (July 2020): 459-62

33 Bandy X. Lee, "Speaking Up About Trump, An Experience of a Lifetime," Room: A sketchbook for Analytic Action (February 2019).

34 Paul Basken, "'Duty to Warn'," Chronicle of Higher Education (Interview), January, 19, 2018.

35 "Dr. Bandy Lee: America's Mental Health Crisis," MeidasTouch.com, November 17, 2020.

36 Bandy X. Lee, "A Psychological Take on the News," November 18, 2020, Twitter.

37 Bandy X. Lee, "A Psychological Take on the News," November 25, 2020, Twitter.

38 Bandy X. Lee et al., "Violence and health: Merging criminal justice, law, mental health, and public health - Part A: Neuroscience, epidemiology, and revisionist discourse," Aggression and Violent Behavior 46 (2019). 
upending domestic policy choices on mental health grounds, she also hoped that her coalition would remake global politics, including ending "the controlling role the U.S. imposes on the world through its imperialistic, and often isolated, policies." ${ }^{39}$ In the millennium of peace to come, "we look to the international community to play a far more significant role, including constraining our dangerous president and containing our national militancy." ${ }^{40}$

The minjung millenarianism of Bandy X. Lee thus declared democracy to be a public health hazard. In the utopia to come, it would be impossible for “political strategists [to] use psychological maneuvering to position people into voting against their own interests." ${ }^{41}$ Mental health experts would screen out candidates they declared nuts: "We must dispel the notion that . . . screening would somehow take away agency from voters." ${ }^{42}$ Lee used her shepherd's crook on anyone who bleated out nonsense about the equality of citizens in a democracy: "It may feel good to think that your opinion is as valid as any expert's, without needing to put in the effort and the time, but it is wishful thinking and not reality." ${ }^{3}$

The endgame, it seems, is not just the small matter of replacing democracy with spiritual-cum-psychoanalytic experts, to "restore societal mental health by removing threats to public health and safety." The longer game is nothing short of a People's Republic of Total Consciousness. For as she noted at the original Yale conference, "politics is nothing more than medicine on a larger scale." ${ }^{44}$

39 Bandy X. Lee, Mark Bruzonsky, "Trump is a threat to peace. It is time for the UN to act on uniting Korea instead," Euronews, January 312020.

40 Lee and Bruzonsky, "Trump is a threat to peace. It is time for the UN to act on uniting Korea instead."

41 Basken, "'Duty to Warn'."

42 Bandy Lee Tweet, November 24, 2020

43 Haycock, "Interview With Yale Forensic Psychiatrist Bandy Lee."

44 Transcript of the Duty to Warn Conference, Yale School of Medicine, April 20, 2017, https://static. macmillan.com/static/duty-to-warn-conference-transcript.pdf. 